\title{
A Comparison between Intrathecal Nalbuphine and Fentanyl for Intraoperative Pain Management during Uterine Exteriorization in Cesarean Section: A Randomized Controlled Trial
}

\author{
Sherif Abdullah Mohamed*(iD, Ahmed Elsonbaty (D), Mohamed Elsonbaty (i) \\ Department of Anesthesia, Surgical ICU and Pain Management, Cairo University, Cairo, Egypt
}

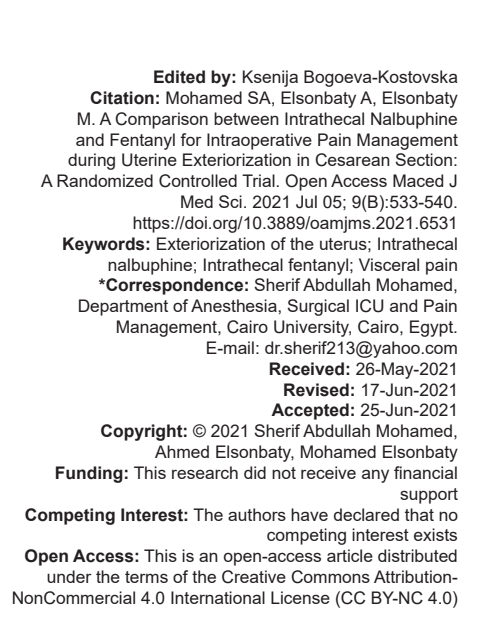

Introduction

Spinal anesthesia is the optimum practice for cesarean delivery (CS). It is easy to administer, has a quick onset, and reduces the risk of aspiration and neonatal depression, as well as providing superior analgesia to general anesthesia (GA) [1]. However, because spinal anesthesia has less control over the block level, it may not provide enough block for visceral pain, particularly during uterine exteriorization. [2], [3], [4].

Increasing the intrathecal local anesthetic dosage may help to reduce the occurrence of intraoperative visceral pain but at the cost of a higher blockage [2]. To improve the block's quality, several adjuvants have been utilized [5]. Intrathecal opioids, for example fentanyl and nalbuphine, are added to local anesthetic agents to provide adequate intraoperative visceral analgesia, reduce the requirement for intraoperative analgesics, and prolong post-operative analgesia [6], [7].
Fentanyl is a synthetic opioid with the analgesic and anesthetic activities. Fentanyl exerts its effect by binding to the mu-receptor in the nervous system. However, mu agonists have well-known adverse events (depressed respiration, unwanted drowsiness, itching, bradycardia, nausea, emesis, and urine retention) [8]. Nalbuphine is an agonist-antagonist opioid that can reduce mu effects while increasing kappa effects. Its combination with mu agonists made mu-receptor associated adverse events less to occur and less severe, and it can also prevent spinal anesthesia caused shivering [9], [10], [11], [12].

Few studies compared nalbuphine and fentanyl when they are added intrathecally to bupivacaine in the spinal block for CS [13], [14], but they did not focus on their use during uterine exteriorization in cesarean section as a condition that aggravates visceral pain under spinal anesthesia. This study will try to answer the question that is intrathecal nalbuphine effective and safe enough in such a scenario to be used routinely as an alternative to fentanyl (which is the commonly used opioid in practice) 


\section{Patients and Methods}

This double-blinded prospective randomized controlled research was undertaken in the theater of obstetric surgery of Cairo University, Kasr Alainy Hospital, between January 2021 and May 2021. After acceptance by the research ethics committee of the Faculty of Medicine of Cairo University (ID: N-7-2021) and after clinicaltrials.gov registry (ID: NCT04689217), 135 cases were enrolled and patients' informed written consents were taken.

\section{Inclusion criteria}

Full-term pregnant patients, cesarean deliveries under spinal anesthesia, 20 and 45 years of age, the American Society of Anesthesiologists physical status (ASA) Class I-II, weight between 60 and $100 \mathrm{~kg}$, and height between 160 and $180 \mathrm{~cm}$ were included in the study.

\section{Exclusion criteria}

ASA III or IV, hypotensive patients, injection site infection, coagulation abnormalities (INR $>$ or $=1.4$, platelet count $<100000$ ), weight $<60$ and $>100 \mathrm{~kg}$, anticoagulation agents, history of central nervous system illness (cerebrovascular insufficiency, intracranial hemorrhage, brain tumor, epilepsy, and multiple sclerosis), uncooperative patients, cardiac disorder (cardiomyopathy with EF < 50, severe valvular lesions, atrial fibrillation, and heart blocks) or respiratory disorder (pneumonic patches, $\mathrm{CO}_{2}$ retention $>50 \mathrm{mmHg}$, hypoxia with $\mathrm{Po}_{2}<60 \mathrm{mmHg}$, and saturation $<95$ in $\mathrm{ABG}$ in room air), body temperature $<36.1$ or $>37.2$, allergy to local anesthetics, and premature or small birth weight neonates were excluded from the study.

Randomization: Based on computergenerated randomization numbers held in sealed envelopes (EPIDAT 4.1), patients were allocated into a 1:1:1 ratio to $F$ group (no. 45 ), $N$ group (no. 45 ), and $C$ group (no. 45) when they arrived in the operating room. A researcher who was not engaged in patient care gave these envelopes to the anesthesiologist in charge of performing spinal anesthesia.

\section{Pre-operative management}

Relevant history taking, examination, and routine investigations were done: $\mathrm{CBC}, \mathrm{PT}, \mathrm{PC}, \mathrm{INR}$, liver enzymes, renal function tests, and random blood sugar.

On arriving at the operation room (OR), the monitors (pulse oximetry, noninvasive arterial blood pressure, and electrocardiography) were attached. OR temperature was adjusted to $24^{\circ} \mathrm{C}$ and the axillary temperature was recorded. An 18 gauge cannula was implanted in a peripheral vein and I.V. Ringer's solution with $10 \mathrm{ml} / \mathrm{kg}$ within $15 \mathrm{~min}$ was infused to the patients before performing the spinal anesthesia.

\section{Intraoperative management}

Patients were instructed to put in the sit and lean forward. With a 25 gauge Quincke needle, a dural puncture was done at the level of the space between $L 4$ and L5 or L3 and L4 after sterilization.

The volume of intrathecal local anesthetic given to each patient was determined by the patient's weight and height table (Table 1), where only the mentioned heights and weights were included in the study [15].

Group F (fentanyl) received an intrathecal injection of $0.5 \%$ heavy bupivacaine plus $0.5 \mathrm{ml}$ fentanyl 25 mg (Sunny Pharmaceutical, Badr City, Egypt, under license of Hameln Pharmaceutical, Germany).

Group N (nalbuphine) received an intrathecal injection of $0.5 \%$ heavy bupivacaine with the addition of $0.5 \mathrm{ml}$ nalbuphine hydrochloride to it $(0.8 \mathrm{mg}=0.5 \mathrm{ml}$ of a $20 \mathrm{mg}$ nalbuphine dissolved in $12.5 \mathrm{ml}$ normal saline) (Amoun Pharmaceutical Co., Cairo, Egypt) [13].

Group C (control) received an intrathecal injection of $0.5 \%$ heavy bupivacaine with $0.5 \mathrm{ml}$ normal saline added to it.

An anesthesiologist performed the spinal injections but did not take part in the data collection. The medications supplied were kept a secret from both the patients and the researchers.

Cases were then positioned as supine with wedging under their right hip to keep the left uterus displaced. A cushion was used to elevate the head, and an oxygen mask (6 L/min) was used.

Ramsey sedation score [16], HR, MAP, and $\mathrm{SpO}_{2}$ were recorded with 5 min intervals after spinal anesthesia. The sensory blocking level was evaluated by pinprick, while motor blocking was evaluated by Bromage scaling; 0 = no movement, 1 = only can move the knees without the hips, 2 = can only move the feet, and 3 = cannot move either the knees or the feet [17]. The block was assessed with 2 min interval to the time

Table 1: Volume of intrathecal local anesthetic in milliliters (ml) according to patient's weight and height

\begin{tabular}{|c|c|c|c|c|c|c|c|c|c|}
\hline \multirow[t]{2}{*}{ Weight (kg) } & \multicolumn{9}{|c|}{ Height $(\mathrm{cm})$} \\
\hline & 140 & 145 & 150 & 155 & 160 & 165 & 170 & 175 & 180 \\
\hline 50 & 1.5 & 1.7 & 1.8 & 1.9 & & & & & \\
\hline 55 & 1.5 & 1.6 & 1.8 & 1.9 & 2 & & & & \\
\hline 60 & 1.4 & 1.6 & 1.7 & 1.8 & 2 & 2.1 & & & \\
\hline 65 & 1.4 & 1.5 & 1.7 & 1.8 & 1.9 & 2.1 & 2.2 & & \\
\hline 70 & 1.3 & 1.5 & 1.6 & 1.8 & 1.9 & 2 & 2.2 & 2.3 & \\
\hline 75 & & 1.4 & 1.6 & 1.7 & 1.9 & 2 & 2.1 & 2.3 & 2.4 \\
\hline 80 & & 1.4 & 1.5 & 1.7 & 1.8 & 2 & 2.1 & 2.2 & 2.4 \\
\hline 85 & & & 1.5 & 1.6 & 1.8 & 1.9 & 2.1 & 2.2 & 2.3 \\
\hline 90 & & & 1.4 & 1.6 & 1.7 & 1.9 & 2 & 2.2 & 2.3 \\
\hline 95 & & & & 1.5 & 1.7 & 1.8 & 2 & 2.1 & 2.3 \\
\hline 100 & & & & 1.5 & 1.7 & 1.8 & 1.9 & 2.1 & 2.2 \\
\hline 105 & & & & & 1.6 & 1.7 & 1.9 & 2 & 2.2 \\
\hline 110 & & & & & & 1.7 & 1.8 & 2 & 2.2 \\
\hline
\end{tabular}


of skin incising and the time that the sensory blockade reached T5 was recorded.

The surgeon was requested not to start before the block reaches T5 dermatome and if the level is not reached by $10 \mathrm{~min}$, tilting down the head for $10^{\circ}$ was adjusted to ensure a better height of the block. If the level is not reached after further $10 \mathrm{~min}$, the patient was excluded from the study. Atropine $(0.01 \mathrm{mg} / \mathrm{kg})$ was delivered if the HR became $<50$ beat $/ \mathrm{min}$. Noradrenaline infusion of $0.05 \mathrm{mic} / \mathrm{kg} / \mathrm{min}$ [18] was initiated following intrathecal injection and ephedrine $10 \mathrm{mg} \mathrm{I.V}$. was delivered if the systolic pressure became $<20 \%$ from the baseline level or $<100 \mathrm{mmHg}$.

After delivery of the baby, an IV shot of 1 unit of oxytocin was given and 7.5 units/h were infused for $4 \mathrm{~h}$ [19]. Visual analog scale (VAS) for visceral abdominal and shoulder pain were assessed every 5 min (from 0 to 10, with varying degrees of escalating pain in between, 0 indicates no pain and 10 indicates extreme excruciating pain) and the maximum score was recorded for $30 \mathrm{~min}$ from the time of baby delivery. For VAS <4, 30 mg IV ketorolac was given slowly [20], For VAS $\geq 4$, increments of $25 \mu \mathrm{g}$ of fentanyl intravenously up to $100 \mu \mathrm{g}$ will be was given and the total fentanyl used was recorded. When VAS persisted to be $\geq 4$ for more than $10 \mathrm{~min}, \mathrm{GA}$ was provided and the case was eliminated from the investigation.

An attendant pediatrician evaluated the Apgar score of the neonate 1 min after birth.

Complications including hypotension, bradycardia, pruritus, nausea, emesis, shivering, and its grades were evaluated by the scale of Crossley and Mahajan as 0 - absent; 1 - piloerection; 2 - activity in one muscle group; 3 - activity in $>1$ group of muscles without generalized shivering; and 4 - whole body shivering, depressed respiration (respiratory rate of $<10$ breaths/min) and hypoxia $\left(\mathrm{SpO}_{2}\right.$ of $\left.<95 \%\right)$ were recorded and managed. For emesis; IV metoclopramide in a dose of $10 \mathrm{mg}$ was given, for itching; a dose of $45.5 \mathrm{mg}$ IV pheniramine maleate were given. Twenty milligrams IV pethidine were given in case of shivering $\geq 3$. In case of respiratory depression, the patient was given GA and eliminated from the investigation.

A urinary catheter was either left in place for $2 \mathrm{~h}$ or removed as soon as the patient was able to walk.

Post-operative management: The time of effective analgesia (from the spinal injection to VAS $\geq$ 4 ) was documented, urine retention after removal of the catheter was reported, and other complications related to spinal block were recorded and managed.

\section{Outcomes}

\section{Primary outcome}

The VAS for visceral abdominal in all groups after uterine exteriorization for $30 \mathrm{~min}$ after baby delivery.

\section{Secondary outcomes}

-

\section{Estimation of sample size}

Sample size was estimated using the G. power 3.1.9.4 software targeting the VAS as the primary outcome using data from a pilot study that was done on 15 patients in every group. This pilot study reported a mean VAS of 3.74, 0.93, and 0.8 in Groups N, F, and C, respectively, with an $\alpha$ of 0.05 and a power of $80 \%$ using the one-way ANOVA for means. The effect size was 2.71 and 135 patients (45/group) were calculated for participation.

\section{Statistical analysis}

Data analysis was done by Statistical Package for the Social Sciences version 21.0., Chicago, Illinois, USA. The mean \pm standard deviation and $95 \%$ confidence interval represented the quantitative data. Qualitative data were shown as the number and percentage of patients. The means were matched using the unpaired Student's t-test. Skewed numerical data were shown as median (range). Medians were matched using the independent samples median test. The proportions between two qualitative parameters were compared using the Chi-squared test. General linear model repeated measures ANOVA was used for comparison of serial measurements within each patient as within-subject effect and group as between subjects' effect. The statistical significance of the two-tailed p-value was ensured when it was $<0.05$. 
6 patients, only from the control, were converted to GA. The demographic characteristics had insignificant differences between groups (Table 2).

Table 2: Demographic characteristics between groups

\begin{tabular}{|c|c|c|c|c|}
\hline & $\begin{array}{l}\text { F group } \\
\text { (no. 45) }\end{array}$ & $\begin{array}{l}\mathrm{N} \text { group } \\
\text { (no. 45) }\end{array}$ & $\begin{array}{l}\text { C group } \\
\text { (no. } 45)\end{array}$ & $p$-value \\
\hline \multirow[t]{2}{*}{ Age (years) } & $28.3(5.3)(95 \%$ & $29.0(4.4)(95 \%$ & $27.6(3.9)(95 \%$ & $* 0.46$ \\
\hline & Cl: 26.8-29.8) & Cl: 27.7-30.3) & Cl: 26.43-28.77) & $\begin{array}{l}* * 0.33 \\
* * * 0.11\end{array}$ \\
\hline \multicolumn{5}{|l|}{ ASA } \\
\hline 1 & $I=34(75.6 \%)$ & $\mathrm{I}=33(73.3 \%)$ & $\mathrm{I}=35(77.8 \%)$ & $* 0.80$ \\
\hline II & $\mathrm{II}=11(24.4 \%)$ & $\mathrm{II}=12(26.7 \%)$ & $\mathrm{II}=10(22.2 \%)$ & $\begin{array}{l}* * 0.80 \\
* * * 0.60\end{array}$ \\
\hline \multirow[t]{2}{*}{ Weight (kg) } & 79.9 (7.3) (95\% & $79.8(8.2)(95 \%$ & $79.3(6.1)(95 \%$ & $* 0.93$ \\
\hline & Cl: 77.8-82) & Cl: 77.4-82.2) & Cl: 77.5-81.1) & $\begin{array}{l}* * 0.84 \\
* * * 0.91\end{array}$ \\
\hline \multirow[t]{2}{*}{ Height $(\mathrm{cm})$} & $171.4(4.7)(95 \%$ & $170.6(5.8)(95 \%$ & $170.9(4.6)(95 \%$ & $* 0.45$ \\
\hline & Cl: $170-172.8)$ & Cl: 168.9-172.3) & Cl:169.5-172.3) & $\begin{array}{l}* * 0.73 \\
* * * 0.69\end{array}$ \\
\hline
\end{tabular}

The onset time and time to Bromage 4 were shortest in $\mathrm{F}$ group with a significant difference from $\mathrm{N}$ and $\mathrm{C}$ groups $(\mathrm{p}<0.05)$. The statistical difference for the duration for two segment regression and time to regress to Bromage 1 was significant between the three groups that it was longest in $\mathrm{N}$ group and shortest in $\mathrm{C}$ group ( $\mathrm{p}<0.05)$. While the maximum reached, sensory level was similar between all groups (Table 3).

Table 3: Spinal block characteristics between groups

\begin{tabular}{|c|c|c|c|c|}
\hline & $\begin{array}{l}\text { F group } \\
\text { (no. 45) }\end{array}$ & $\begin{array}{l}\mathrm{N} \text { group } \\
\text { (no. 45) }\end{array}$ & $\begin{array}{l}\text { C group } \\
\text { (no. 45) }\end{array}$ & $\mathrm{p}$-value \\
\hline Maximum reached & $4: 3-4$ & $4: 3-4$ & $4: 3-4$ & $* 0.49$ \\
\hline sensory level & $\mathrm{T} 2=3(6.7 \%)$ & $\mathrm{T} 2=3(6.7 \%)$ & $\mathrm{T} 2=2(4.4 \%)$ & $* * 0.32$ \\
\hline & $\mathrm{T} 3=12(26.7 \%)$ & $\mathrm{T} 3=11(24.4 \%)$ & $\mathrm{T} 3=11(24.4 \%)$ & $* * * 0.78$ \\
\hline & $\mathrm{T} 4=27(60 \%)$ & $\mathrm{T} 4=24(53.3 \%)$ & $\mathrm{T} 4=27(60 \%)$ & \\
\hline & $\mathrm{T} 5=3(6.7 \%)$ & $\mathrm{T} 5=7(15.6 \%)$ & $\mathrm{T} 5=5(11.1 \%)$ & \\
\hline Onset time (time & $3.64(0.73)(95 \%$ & $4.02(0.74)(95 \%$ & $4.9(1.16)(95 \%$ & $* 0.02$ \\
\hline $\begin{array}{l}\text { in minutes to } \\
\text { reach to sensory } \\
\text { level of T5) }\end{array}$ & Cl: 3.34-3.85) & Cl: 3.80-4.24) & $\mathrm{Cl}: 4.4$ to 5.4 ) & $\begin{array}{l}* * 0.0002 \\
* * *<0.0001\end{array}$ \\
\hline Time in minutes to & $4.66(0.70)(95 \%$ & 5 (0.73) (95\% Cl: & $5.28(0.85)(95 \%$ & $* 0.03$ \\
\hline Bromage 4 & $\mathrm{Cl}: 4.46-4.86)$ & $5.51-5.95)$ & Cl: 4.81-5.71) & $\begin{array}{l}* * 0.09 \\
* * * 0.002\end{array}$ \\
\hline $\begin{array}{l}\text { Time in minutes } \\
\text { to two segment } \\
\text { regression }\end{array}$ & $\begin{array}{l}108.20 \text { (7.41) } \\
\text { (95\% Cl: }\end{array}$ & $\begin{array}{l}120.48 \text { (9.99) } \\
\text { (95\% Cl: }\end{array}$ & $\begin{array}{l}89.34 \text { (12.23) } \\
\text { (95\% Cl: }\end{array}$ & $\begin{array}{l}*<0.0001 \\
* *<0.0001\end{array}$ \\
\hline Time in minutes & $144.22(12.38)$ & $148.44(12.05)$ & $111.08(7.26)$ & $* 0.06$ \\
\hline to regress to & (95\% Cl: & (95\% Cl: & (95\% Cl: & $* *<0.0001$ \\
\hline Bromage 1 & $140.61-147.83)$ & $144.92-151.96)$ & 107.91-113.14) & $* * *<0.0001$ \\
\hline
\end{tabular}

The incidence and VAS of the visceral abdominal after uterine exteriorization showed an insignificant difference between group $\mathrm{F}$ and $\mathrm{N}$, however, the difference was highly significant between both groups and $\mathrm{C}$ group. Also, the rescue fentanyl showed insignificant difference between group $\mathrm{F}$ and $\mathrm{N}$, but with highly significant difference between both groups and $\mathrm{C}$ group as regards its mean dose and the number of patients who needed it.

The incidence of shoulder pain had a statistically significant difference between $C$ group and the other two groups, while its VAS was significantly different only between $\mathrm{N}$ and $\mathrm{C}$ groups. Effective analgesia duration had a highly significant difference between all groups (Table 4).
Table 4: Analgesic performance between groups

\begin{tabular}{|c|c|c|c|c|}
\hline & $\begin{array}{l}\text { F group } \\
\text { (no. 45) }\end{array}$ & $\begin{array}{l}\mathrm{N} \text { group } \\
\text { (no. } 45 \text { ) }\end{array}$ & $\begin{array}{l}\text { C group } \\
\text { (no. 45) }\end{array}$ & $p$-value \\
\hline \multicolumn{5}{|l|}{ Visceral pain } \\
\hline Incidence & $10(22.2 \%$ & $11(24.4 \%)$ & $30(66.7 \%)$ & $\begin{array}{l}* 0.80 \\
* *<0.0001 \\
* * *<0.0001\end{array}$ \\
\hline VAS & $0.76(1.6)(95 \%$ & 0.87 (1.7) (95\% Cl: & $3.9(2.5)(95 \%$ & $* 0.77$ \\
\hline & Cl: $0.29-1.23)$ & $0.37-1.37)$ & $\mathrm{Cl}: 3.2-4.6)$ & $\begin{array}{l}* *<0.0001 \\
* * *<0.0001\end{array}$ \\
\hline \multicolumn{5}{|l|}{ Shoulder pain } \\
\hline Incidence & $2(4 \%)$ & $1(2.2 \%)$ & $8(17.8 \%)$ & $\begin{array}{l}* 0.55 \\
* * 0.04 \\
* * * 0.0001\end{array}$ \\
\hline \multirow[t]{2}{*}{ VAS } & $0.16(0.73)(95 \%$ & $0.07(0.44)(95 \%$ & $0.7(1.6)(95 \%$ & $* 0.18$ \\
\hline & Cl: $0.04-0.36)$ & Cl: $0.05-0.19)$ & $\mathrm{Cl}: 0.2-1.2)$ & $\begin{array}{l}* * 0.27 \\
* * * 0.01\end{array}$ \\
\hline Effective & $225.1(14.9)$ & 240.2 (19.61) (95\% & 162.4 & $* 0.0002$ \\
\hline analgesia duration & (95\% Cl: & Cl: 234.5-245.9) & (14.3) $(95 \%$ & $* *<0.0001$ \\
\hline $\begin{array}{l}\text { (in minutes) } \\
\text { Rescue fentanyl }\end{array}$ & \multicolumn{3}{|c|}{ Rescue fentanyl } & $* * *<0.0001$ \\
\hline $\begin{array}{l}\text { Patients } \\
\text { needed }\end{array}$ & $3(6.7 \%)$ & $5(11.1 \%)$ & $27(60 \%)$ & $\begin{array}{l}* 0.45 \\
* * 0.0001 \\
* * *<0.0001\end{array}$ \\
\hline $\begin{array}{l}\text { Mean dose of } \\
\text { fentanyl }\end{array}$ & $\begin{array}{l}3.3(12.5)(95 \% \\
\text { Cl: } 0.4-7)\end{array}$ & $\begin{array}{l}5.6(15.7)(95 \% \mathrm{Cl}: \\
1-10.2)\end{array}$ & $\begin{array}{l}38.6(36.4) \\
(95 \% \mathrm{Cl}: \\
28-49.2)\end{array}$ & $\begin{array}{l}* 0.49 \\
* *<0.0001 \\
* * *<0.0001\end{array}$ \\
\hline
\end{tabular}

As regards the incidence of the recoded complications, the statistical difference for nausea and vomiting was highly significant between $\mathrm{N}$ and $\mathrm{C}$ groups, significant between $\mathrm{F}$ and $\mathrm{C}$ groups, while it was significant between $\mathrm{F}$ and $\mathrm{N}$ groups only for nausea. Shivering incidence and grades were significantly different between all groups and the difference was highly significant between $\mathrm{N}$ and $\mathrm{C}$ groups. Itching was not noticed in groups $\mathrm{N}$ and $\mathrm{C}$ while it occurred in 14 (31.1\%) patients that the statistical difference was highly significant between $\mathrm{C}$ group and both $\mathrm{N}$ and $\mathrm{C}$ groups ( $\mathrm{p}<0.001)$. The occurrence of bradycardia was significantly less in Groups $\mathrm{N}$ and $\mathrm{C}$ than in $\mathrm{F}$ and it did not differ between $\mathrm{N}$ and $\mathrm{C}$ groups. Hypotension was comparable between groups. Urine retention occurred only in one patient in $\mathrm{F}$ group with no incidence reported in the other groups. Depressed respiration was not reported in any group (Table 5).

Sedation scores were higher in a significant way in $\mathrm{F}$ and $\mathrm{N}$ groups than $\mathrm{C}(\mathrm{p}<0.05)$ with an insignificant difference between $\mathrm{F}$ and $\mathrm{N}$ groups. Apgar scores were not significantly different between the compared groups and no complications existed in the neonates of any group (Table 5). Oxygen saturation showed an insignificant difference between groups $(p>0.05)$ with no reported episodes of desaturation in any group.

The comparison for HR had a significant difference between $\mathrm{F}$ group and both $\mathrm{N}(\mathrm{F}[1]=5.15$ and $p=0.008)$ and $C(F[1]=5.78$ and $p=0.006)$ groups, while it was statistically insignificant between $\mathrm{N}$ and $\mathrm{C}$ groups $(F[1]=0.002$ and $p=0.97)$ (Figure 1).

\section{Discussion}

This double-blinded randomized controlled research was done to evaluate the analgesic 


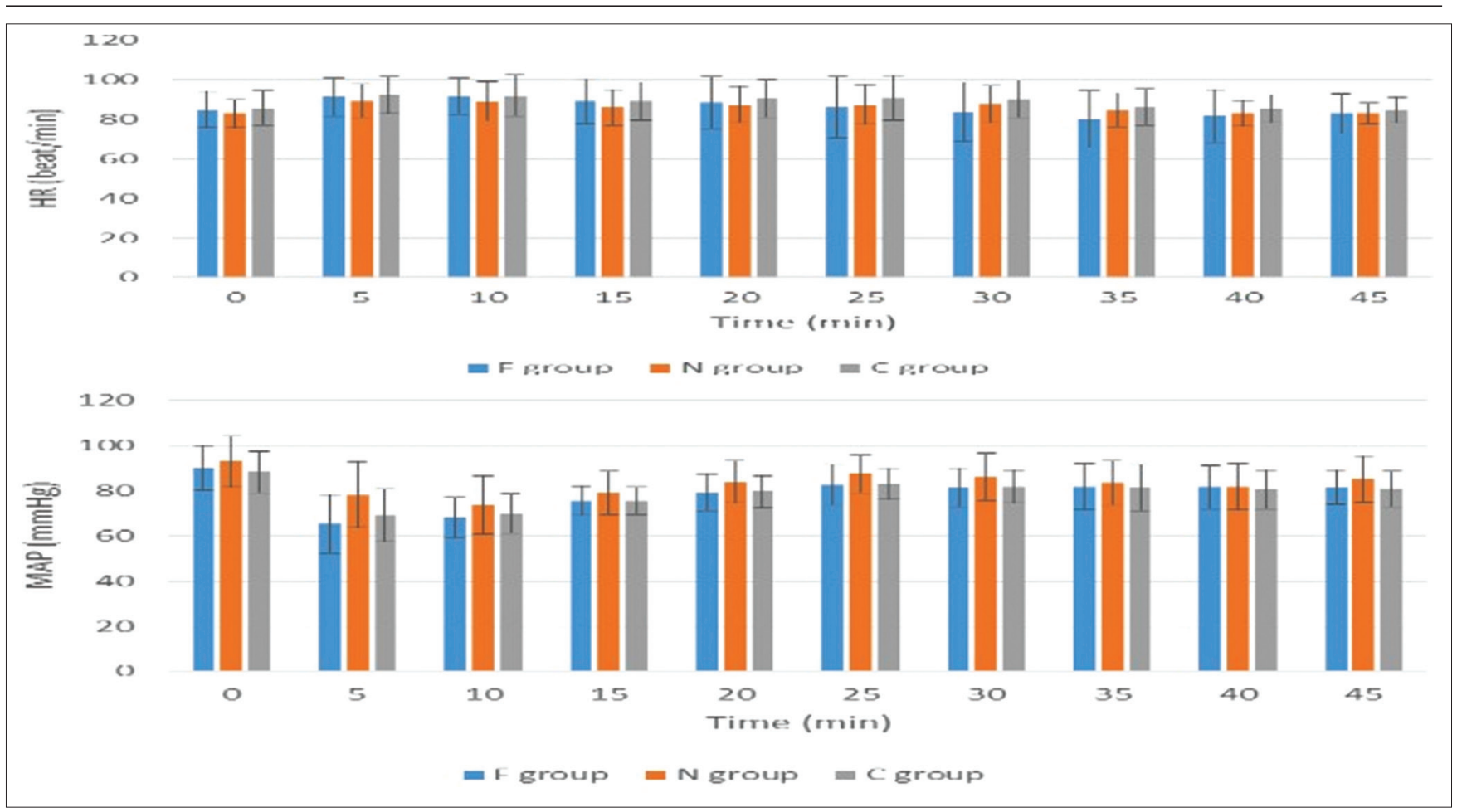

Figure 1: Intraoperative HR and MAP trends between groups during the recording period. The columns are for estimated means and the error bars are for standard deviation

Table 5: Comparison of the incidence of complications, sedation, and Apgar scores between groups

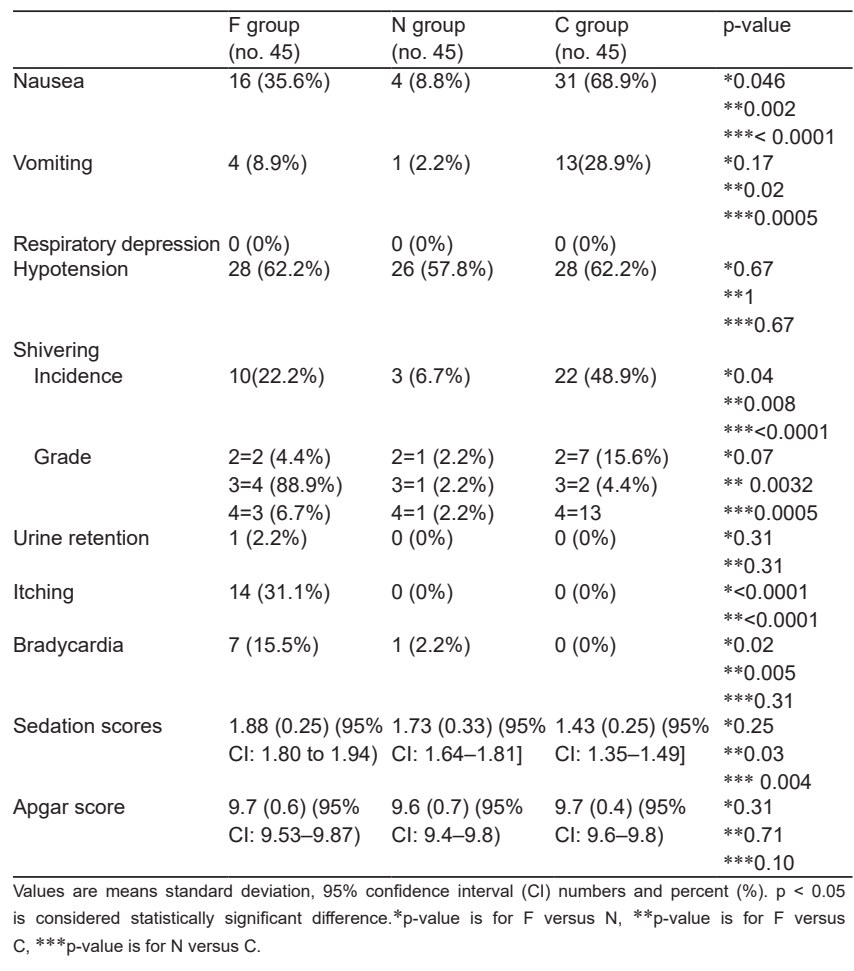

performance and safer profile of intrathecal nalbuphine and intrathecal fentanyl when used as adjuvants to spinal anesthesia to control visceral pain induced by uterine exteriorization maneuver during cesarean section. The target was to investigate the possibility to replace intrathecal fentanyl which is the widely used intrathecal opioid adjuvant with intrathecal nalbuphine which was hypothesized to be effective as fentanyl with fewer side effects that were encountered with fentanyl. Although the comparison between the two agents was investigated in some studies, there is almost no study that compared their preference during exteriorization of the uterus which was reported to cause a more frequent prevalence of moderate to maximum pain [4]. Our hypothesis was supported by the results of the study.

Intrathecal nalbuphine was comparable to intrathecal fentanyl as regards the incidence and VAS of visceral pain and shoulder pain, number of patients who needed rescue IV fentanyl and its mean dose. Previous research in rats showed that both $m u$ and $k$ receptors regulate visceral analgesia and that intrathecal nalbuphine decreases visceral pain responses [21], [22]. Intrathecal opioids bind to their receptors in the dorsal horn in the spinal cord, causing segmental analgesia. These opioids extend the analgesic period without compromising motor or autonomic nerve ability. The regressing of the sensory blockade is prolonged more than that found with local anesthetics alone when these opioids were combined with intrathecal local anesthetics. The most significant adverse consequence of the intrathecal mu opioids is depressed respiration, whereas itching has the highest prevalence. Nausea, vomiting, urinary retention, and drowsiness are some of their other side effects [23], [24].

In this work, the chosen dose of nalbuphine $(0.8 \mathrm{mg})$ was based on the investigation of Culebras et al. [25] and Jyothi et al. [26]. They showed an analgesic ceiling effect of nalbuphine as when they increased nalbuphine dosage from $0.8 \mathrm{mg}$ to $1.6 \mathrm{mg}$ 
and $2.4 \mathrm{mg}$ no further analgesia was encountered.

For more than a decade, nalbuphine has been used neuraxially in modern anesthesia. Since then, no instances of neurotoxicity from intrathecal nalbuphine have been reported. A previous animal study found no behavioral or systematic histopathologic abnormalities. [27]. Trials on humans with intrathecal nalbuphine in pregnant cases were also undertaken, but no neurotoxicity was detected [25], [28].

Nalbuphine binds to mu receptors with no agonistic action and displaces other mu antagonists from the receptor in a competitive manner. When it interacts to kappa receptors, however, it exerts an agonistic action. As a result, it is an agonist-antagonist and it provides analgesic effects without causing mu adverse effects [9], [10], [11], [12].

Intrathecal nalbuphine had a significantly less prevalence and lower shivering grades than the other groups. Even though IV nalbuphine has long been used to treat post-anesthetic shivering, it is most commonly used to treat shivering that has already started [29], [30]. Nalbuphine has a strong affinity for the central nervous system's k-opioid receptors. Hence, it exerts its potential anti-shivering actions through this channel. Many studies have shown that k-opioid receptors are more important contributor in the therapy of post-spinal shivering than mu-opioid receptors. [31], [32]. Our results were agreed with the studies of Farahat and Ashraf et al. [33], [34].

Itching incidence was significantly lower with intrathecal nalbuphine. The mechanism of intrathecal opioid-induced itching cannot be linked to histamine release [35]. Itching can be as a result of the spread of the opioids to the "Itch Center" in the medulla, then they affect the trigeminal nucleus [24]. Furthermore, it may be due to that pain and itching have the same afferent unmyelinated $C$ fibers [36]. The most widely accepted idea is that itching is controlled by mu-opioid receptors, which are responsible for pain perception as well as various adverse effects, including pruritus, nausea, and vomiting. Because both nalbuphine are a specific antagonist, this would explain their antipruritic activity [37], [38], [39]. Yoon et al. compared intrathecal morphine, nalbuphine, and morphine with nalbuphine in 60 cases of CS and found that effective analgesia had more duration in the morphine and combined morphine/ nalbuphine groups, while the rate of occurrence of itching was much reduced with nalbuphine [40].

In addition, intrathecal nalbuphine caused significantly less bradycardia than fentanyl, and the HR of the two groups differed significantly. Fentanyl has negligible impact on systemic circulation in general, however, it is associated with vagally driven bradycardia. [41].

Culebras et al. [25] had similar results to our study that the rate of occurrence of nausea was significantly lesser in $\mathrm{N}$ group compared to the other two groups. It is thought that stimulating the chemoreceptor trigger zone is the cause of fentanyl-induced nausea and vomiting [24].

Sedation scores were higher with intrathecal fentanyl than the other two groups. The findings of Bindra et al. and Cowan et al. were comparable to our study [42], [43] while Gupta et al. showed comparable sedation scores but they used a dose of $2 \mathrm{mg}$ nalbuphine [44].

The time for block onset and the regression time for the sensory and motor blockade were significantly longer in the cases of $\mathrm{N}$ than $\mathrm{F}$ group. It can be linked to the high lipid solubility, rapid uptake into the tissue of fentanyl relative to nalbuphine [45]. These results were similar to investigations of Bisht et al. [46], Gupta et al. [44], and Gurunath et al. [47]. These investigations were done on different surgeries including gynecological, orthopedic, and lower abdominal surgeries. While intrathecal nalbuphine had a significantly more time of effective analgesia, these results were in line with the previous researches of Tiwari et al. [48] and Gupta et al. [44].

All groups had a comparable Apgar score and comparable incidence of hypotension, no reported respiratory depression, no hypoxic episodes, and no urine retention (except one in $\mathrm{F}$ group).

\section{Limitations}

The main limitations of our study were that some side effects (as urine retention) needed a larger sample for better evaluation, however, this did not affect the significance of the results. The study did not include patients with height $<160$ or $>180 \mathrm{~cm}$ and weight $<60$ or $>100 \mathrm{~kg}$. We used norepinephrine that could decrease HR, but it was applied to all groups with the same dose. Different doses of intrathecal agents were not evaluated, however, the chosen doses in this study were based on the previous studies. These limitations give potential ideas for future researches.

\section{Conclusion}

The results of this study revealed that intrathecal nalbuphine had a similar incidence and VAS of visceral pain and shoulder pain, a comparable number of patients who needed rescue IV fentanyl and its mean dose to intrathecal fentanyl. Furthermore, it had significantly less incidence of nausea, shivering, itching, bradycardia, and lower sedation scores. Hence, it can be concluded that intrathecal nalbuphine can be considered an effective safer alternative to intrathecal fentanyl when used to alleviate the visceral pain induced by uterine exteriorization during cesarean section. 


\section{References}

1. Rudra A, Halder R, Sen A, Kundu S. Efficacy of low dose propofol for control of emetic episodes during cesarean delivery with spinal anesthesia. Indian J Anesth. 2004;48:31-4.

2. Alahuhta $S$, Kangas-Saarela $T$, Hollmén Al, Edström $H H$. Visceral pain during caesarean section under spinal and epidural anaesthesia with bupivacaine. Acta Anaesthesiol Scand. 1990;34(2):95-8. https://doi.org/10.1111/j.1399-6576.1990. tb03050.x PMid:2407045

3. Uzma Y, Saima N. Extra-abdominal versus intra-abdominal uterine repair: A randomized control trial. Pak J Med Health Sci. 2012;6(2):471.

4. Pedersen H, Santos AC, Steinberg ES, Schapiro HM, Harmon TW, Finster M. Incidence of visceral pain during cesarean section: The effect of varying doses of spinal bupivacaine. Anesth Analg. 1989;69(1):46-9. https://doi. org/10.1213/00000539-198907000-00009

PMid:2742167

5. Goma HM, Flores-Carrillo JC, Whizar-Lugo V. Spinal additives in subarachnoid anaesthesia for cesarean section. In: Topics in Spinal Anaesthesia. United Kingdom: Intech Open; 2014. https://doi.org/10.5772/58851

6. Gauchan S, Thapa C, Prasai A, Pyakurel K, Joshi I, Tulachan J. Effects of intrathecal fentanyl as an adjunct to hyperbaric bupivacaine in spinal anesthesia for elective caesarean section. Nepal Med Coll J. 2013;15:156-9.

7. Förster JG, Rosenberg $\mathrm{PH}$. Clinically useful adjuvants in regional anaesthesia. Curr Opin Anaesthesiol. 2003;16(5):47786. https://doi.org/10.1097/00001503-200310000-00007 PMid:17021500

8. Sharma AK, Nareda M, Aziz S, Sharma D, Garg DS. Fentanyl-a potent opioid analgesic: A review. J Dev Drugs. 2016;5(3):3-6. https://doi.org/10.4172/2329-6631.1000162

9. Eisenach JC, Carpenter R, Curry R. Analgesia from a peripherally active Kappa-opioid receptor agonist in patients with chronic pancreatitis. Pain. 2003;101(1-2):89-95. https://doi. org/10.1016/s0304-3959(02)00259-2

PMid:12507703

10. Charuluxananan $S$, Kyokong $\mathrm{O}$, Somboonviboon W, Lertmaharit $S$, Ngamprasertwong P, Nimcharoendee K. Nalbuphine versus propofol for treatment of intrathecal morphine-induced pruritus after cesarean delivery. Anesth Analg. 2001;93(1):162-5. https:// doi.org/10.1097/00000539-200107000-00032

PMid:11429358

11. Jyothi B, Gowda S, Shaikh SI. A comparison of analgesic effect of different doses of intrathecal nalbuphine hydrochloride with bupivacaine and bupivacaine alone for lower abdominal and orthopedic surgeries. Indian J Pain. 2014;28(1):18-23. https:// doi.org/10.4103/0970-5333.128881

12. Ahmed Fl. Intrathecal nalbuphine versus fentanyl as an adjuvant to bupivacaine in spinal anesthesia for elective cesarean section: A randomized double-blind study. Res Opin Anesth Intensive Care. 2019;6:112-8. https://doi.org/10.4103/ roaic.roaic_109_17

13. Gomaa HM, Mohamed NN, Zoheir HA, Ali MS. A comparison between post-operative analgesia after intrathecal nalbuphine with bupivacaine and intrathecal fentanyl with bupivacaine after cesarean section. Egypt J Anaesth. 2014;3:8. https://doi. org/10.1016/j.egja.2014.03.008

14. Babu KV, Kumar GP, Harinath G. Evaluation of the efficacy of intrathecal fentanyl versus intrathecal nalbuphine as adjuvants to $0.75 \%$ ropivacaine for post-operative pain relief in cesarean section: A double-blind randomized comparative study. Int J Sci
Stud. 2017;5(1):5-10. https://doi.org/10.4103/aer.aer_41_18

15. Harten JM, Boyne I, Hannah P, Varveris D, Brown A Effects of a height and weight adjusted dose of local anaesthetic for spinal anaesthesia for elective Caesarean section. Anaesthesia. 2005;60(4):348-53. https://doi. org/10.1111/j.1365-2044.2005.04113.x

PMid: 15766337

16. Ramsay MA, Savege TM, Simpson BR, Goodwin R. Controlled sedation with alphaxalone-alphadolone. $\mathrm{Br}$ Med $\mathrm{J}$. 1974;2(5920):656-9. https://doi.org/10.1136/bmj.2.5920.656 PMid:4835444

17. Bromage PR, editor. Epidural Analgesia. Philadelphia, PA: WB Saunders; 1978. p. 144.

18. Hasanin AM, Amin SM, Agiza NA, Elsayed MK, Refaat S, Hussein HA, et al. Norepinephrine infusion for preventing postspinal anesthesia hypotension during cesarean delivery: Arandomized dose-finding trial. Anesthesiology. 2019;130(1):5562. https://doi.org/10.1097/aln.0000000000002483 PMid:30335625

19. Heesen M, Carvalho B, Carvalho JC, Duvekot JJ, Dyer RA, Lucas DN, et al. International consensus statement on the use of uterotonic agents during caesarean section. Anaesthesia. 2019;74(10):1305-19. https://doi.org/10.1111/anae.14757 PMid:31347151

20. Abbas MS, Askar OA, Abdel-Aleem AA. Pre-emptive ketorolac for prevention of intraoperative shoulder pain in patients undergoing cesarean section: A double blind randomized clinical trial. Asian J Anesthesiol. 2017;55(3):68-72. https://doi. org/10.1016/j.aja.2017.07.002

PMid:28993164

21. Schmauss C, Doherty C, Yaksh TL. The analgetic effects of an intrathecally administered partial opiate agonist, nalbuphine hydrochloride. Eur J Pharmacol. 1982;86(1):1-7. https://doi. org/10.1016/0014-2999(82)90389-2

PMid:6897635

22. Schmauss C, Doherty C, Yaksh TL. In vivo studies on spinal opiate receptor systems mediating antinociception. II. Pharmacological profiles suggesting a differential association of mu, delta and kappa receptors with visceral chemical and cutaneous thermal stimuli in the rat. $\mathrm{J}$ Pharmacol Exp Ther. 1984;228(1):1-12.

PMid:6319664

23. Tawfik MO. Mode of action of intraspinal opioids. Pain Rev. 1994;1:275-94.

24. Chaney MA. Side effects of intrathecal and epidural opioids. Can J Anaesth. 1995;42(10):891-903. https://doi.org/10.1007/ bf03011037

PMid:8706199

25. Culebras X, Gaggero G, Zatloukal J, Kern C, Marti RA. Advantages of intrathecal nalbuphine, compared with intrathecal morphine, after cesarean delivery: An evaluation of postoperative analgesia and adverse effects. Anesth Analg. 2000;91(3):601-5. https://doi.org/10.1097/00000539-200009000-00019 PMid: 10960384

26. Jyothi B, Gowda S, Shaikh SI. A comparison of analgesic effect of different doses of intrathecal nalbuphine hydrochloride with bupivacaine and bupivacaine alone for lower abdominal and orthopedic surgeries. Indian J Pain. 2014;28(1):18-21. https:// doi.org/10.4103/0970-5333.128881

27. Rawal N, Nuutinen L, Raj PP, Lovering SL, Gobuty AH, Hargardine $\mathrm{J}$, et al. Behavioral and histopathologic effects following intrathecal administration of butorphanol, sufentanil, and nalbuphine in sheep. Anesthesiology. 1991;75(6):1025-34. https://doi.org/10.1097/00000542-199112000-00015

PMid:1835823 
28. Yang T, Breen TW, Archer D, Fick G. Comparison of $0.25 \mathrm{mg}$ and $0.1 \mathrm{mg}$ intrathecal morphine for analgesia after cesarean section. Can J Anaesth. 1999;46(9):627-60. https://doi. org/10.1007/bf03012975

PMid:10490154

29. Kranke $\mathrm{P}$, Eberhart LH, Roewer N, Tramèr MR. Pharmacological treatment of postoperative shivering A quantitative systematic review of randomized controlled trials. Anesth Analg. 2002;94(2):453-60. https://doi. org/10.1213/00000539-200202000-00043

PMid:11812718

30. Haque MF, Rashid MH, Rahaman MS, Islam MR. Comparison between tramadol hydrochloride and nalbuphine hydrochloride in the treatment of per-operative shivering after spinal anaesthesia. Mymensingh Med J. 2011;20(2):201-5. PMid:21522088

31. Wang JJ, Ho ST, Lee SC, Liu YC. A comparison among nalbuphine, meperidine, and placebo for treating postanesthetic shivering. Anesth Analg. 1999;88(3):686-9. https://doi. org/10.1213/00000539-199903000-00041 PMid: 10072029

32. Ikeda T, Kurz A, Sessler DI, Go J, Kurz M, Belani K, et al. The effect of opioids on thermoregulatory responses in humans and the special antishivering action of meperidine. Ann N Y Acad Sci. 1997;813:792-8. https://doi.org/10.1111/j.1749-6632.1997. tb51783.x

\section{PMid:9100971}

33. Farahat A. Intrathecal nalbuphine versus fentanyl as an adjuvant to bupivacaine in spinal anesthesia for elective cesarean section: A randomized double-blind study. Res Opin Anesth Intensive Care. 2019;1(6):1112-8. https://doi.org/10.4103/roaic. roaic_109_17

34. Eskandr AM, Ebeid AM. Role of intrathecal nalbuphine on prevention of postspinal shivering after knee arthroscopy. Egypt J Anaesth. 2016;32(3):371-4. https://doi.org/10.1016/j. egja.2016.01.002

35. Wittels B, Glosten B, Faure EA, Moawad AH, Ismail M, Hibbard $\mathrm{J}$, et al. Opioid antagonist adjuncts to epidural morphine for postcesarean analgesia: Maternal outcomes. Anesth Analg. 1993;77(5):925-32. https://doi. org/10.1213/00000539-199311000-00009

PMid:8214728

36. Lowitt MH, Bernhard JD. Pruritus. Semin Neurol. 1992;12(4):374-84.

PMid: 1485047

37. Henderson SK, Cohen H. Nalbuphine augmentation of analgesia and reversal of side effects following epidural hydromorphone. Anesthesiology. 1986;65(2):216-8. https://doi. org/10.1097/00000542-198608000-00017 PMid:2426995

38. Lin ML. The analgesic effect of subarachnoid administration of tetracaine combined with low dose of morphine or nalbuphine for spinal anaesthesia. Ma Zui Xue Za Zhi. 1992;30(2):101-5. PMid:1528093

39. Fournier R, Gamulin Z, Macksay M, van Gessel E. Intrathecal morphine versus nalbuphine for postoperative pain relief after total hip replacement. Anesthesiology. 1998;89:867. https://doi. org/10.1034/j.1399-6576.2000.440808.x

40. Yoon JY, Jee YS, Hong JY. A comparison of analgesic effects and side effects of intrathecal morphine, nalbuphine and morphine-nalbuphine mixture for pain relief during a caesarean section. Korean J Anaesthesiol. 2002;42:627-33. https://doi. org $/ 10.4097 / \mathrm{kjae} .2002 .42 .5 .627$

41. Graves CL, Downs NH, Browne AB. Cardiovascular effects of minimal analgesic quantities of Innovar, fentanyl, and droperidol in man. Anesth Analg. 1975;54(1):15-23. https://doi. org/10.1213/00000539-197501000-00002

PMid:1167751

42. Bindra TK, Kumar P, Jindal G. Postoperative analgesia with intrathecal nalbuphine versus intrathecal fentanyl in cesarean section: A double-blind randomized comparative study. Anesth Essays Res. 2018;12(2):561-5. https://doi.org/10.4103/aer. aer_41_18

PMid:29962635

43. Cowan CM, Kendall JB, Barclay PM, Wilkes RG. Comparison of intrathecal fentanyl and diamorphine in addition to bupivacaine for caesarean section under spinal anaesthesia. $\mathrm{Br} \mathrm{J}$ Anaesth. 2002;89(3):452-8. https://doi.org/10.1093/bja/89.3.452 PMid: 12402725

44. Gupta K, Rastogi B, Gupta PK, Singh I, Bansal M, Tyagi V. Intrathecal nalbuphine versus intrathecal fentanyl as adjuvant to $0.5 \%$ hyperbaric bupivacaine for orthopedic surgery of lower limbs under subarachnoid block: Acomparative evaluation. Indian J Pain. 2016;30:9-5. https://doi.org/10.4103/0970-5333.186463

45. Mather LE. Opioid pharmacokinetics in relation to their effects. Anaesth Intensive Care. 1987;15(1):15-22. https://doi. org/10.1177/0310057x8701500104 PMid:2882700

46. Bisht S, Rashmi D. Comparison of intrathecal fentanyl and nalbuphine: A prospective randomized controlled study in patients undergoing total abdominal hysterectomy. Anaesth Pain Intensive Care. 2017;21:194-8.

47. Gurunath BB, Madhusudhana R. Postoperative analgesic efficacy of intrathecal fentanyl compared to nalbuphine with bupivacaine in spinal anesthesia for lower abdominal surgeries. Anesth Essays Res. 2018;12(2):535-8. https://doi.org/10.4103/ aer.aer_55_18

PMid:29962630

48. Tiwari AK, Tomar GS, Agrawal J. Intrathecal bupivacaine in comparison with a combination of nalbuphine and bupivacaine for subarachnoid block: A randomized prospective doubleblind clinical study. Am J Ther. 2013;20(6):592-5. https://doi. org/10.1097/mjt.0b013e31822048db

PMid:21904194 